\title{
What Do We Learn from Daily Leaders and Laggards in Stock Investment? Do They Help Outperform the Market Average?
}

\author{
Doh-Khul Kim ${ }^{1}$ \& Sung-Min Kim ${ }^{2}$ \\ ${ }^{1}$ Department of Accounting and Finance, North Central College, Naperville, IL, USA \\ ${ }^{2}$ Weatherhead School of Management, Case Western Reserve University, Cleveland, OH, USA \\ Correspondence: Doh-Khul Kim, Professor, Department of Accounting and Finance, 30 N. Brainard St., North \\ Central College, Naperville, IL 60540, USA. Tel: 630-637-5243.
}

Received: December 11, 2021

Accepted: January 3, 2022

Online Published: January 7, 2022

doi:10.5539/ijef.v14n2p44

URL: https://doi.org/10.5539/ijef.v14n2p44

\begin{abstract}
Investors generally believe that rising stocks are more likely to maintain their trend and rise going forward, whereas the losing stocks look more price attractive. This belief can lead the investors to expect that they can outperform the average market by trading the stocks purely based on the price movements. However, this research finds that this simple trading strategy does not effectively outperform the market. Nonetheless, we find five sectors of rising stocks and three sectors of declining stocks that outperform the average market in this limited study.
\end{abstract}

Keywords: leaders, laggards, daily trade, outperformance

JEL: G10 (General Financial Markets).

\section{Introduction}

Investors utilize various strategies based on fundamental data (for fundamental analysis) and technical tools (for technical analysis) to outperform the average stock market. Even though there is no robust consensus regarding which one is better than the other, numerous papers show advantages of using technical tools in investment in the stock market. In their review paper, Dev Shah and Zulkernine (2019) effectively summarized the benefits of using technical analysis based on several previous studies.

Various technical tools have been proposed to outperform the average stock market, which is at odds with the Efficient Market Hypothesis (EMH). According to the EMH, as introduced by Fama (1970), it is nearly impossible to beat the average market consecutively using the data available to the public in the long term. However, numerous papers show the technical tools and models that can help identify the best times to buy and sell, eventually leading to better returns than the average market (Leigh et al., 2008; Rarracho et al., 2010).

One common finding of the previous works is that investors exhibit over-reaction (positive and negative) to both good and bad news, at least in the short term. So, investors tend to capture the portion of over-responses in the stock price movement, which will help raise returns. Those over-responses can be captured using mathematical and statistical tools (Kudryavtsev, 2017, 2018, and 2019), and such successful capturing can cause returns to outperform the average market in the long term, even though such capturing can be made in the short term (even daily).

In this research, we intend to investigate whether one can outperform the average market using simple trading strategy. The strategy is simple but rarely discussed by previous research. Following the works of Kudryavtsev (2019), we tried to determine whether any big stock price movements provide any investment opportunities for daily trading, assuming that the over-reaction is possible. By taking a look at firm's daily stock price movements on the next trading session following prior-day movements (up or down), we intend to find a meaningful way of outperforming the average market.

If firms' stock prices on the next trading day move substantially in the opposite direction, we can insist that an over-response occurred during the prior session. If this is the case, we can simply take a counter action for daily trading for firms that were beaten down or soaring. Simply sell firms whose prices are soaring or buy firms being beaten down for one-day holding, which is similar to contrarian investment. However, if no meaningful 
over-response is found, such a strategy will not work.

If the stock prices of firms on the next day move in the same direction on the next trading day, soaring stocks keep rising, and crashed stocks keep declining. Hence, it will be more logical to take the same action. Even though there is a saying that chasing the market (or a firm) is a dangerous strategy on Wall Street, we find meaningful predicting power regarding the next day's session based on the day's big movements.

In this research, we find that daily trading of any randomly selected firms whose stock prices moved in double-digits up or down underperforms the average market. Hence, unlike the work of Kudryavtsev (2019), any big price movements do not provide any consistent over-reaction or momentum (up and down) for short-term trading at an aggregate level. However, if we narrow the daily trading down to specific sectors, the returns outperform the average market. There are 5 sectors in leaders and 3 sectors in laggards whose annual returns outperformed the average market. This paper discusses the data and findings in Sections 2 and 3, and concluding remarks are provided in Section 4.

\section{Data}

For daily stock price responses, we collected data from the Bloomberg platform. Among many market index data, this research uses daily weighted Bloomberg US Aggregate Equity Price Return Index (AGGE). Using the index AGGE ranging from September 1, 2019 to September 4, 2020, is one of the main differences from the extant research. As one of the broadest indexes, the AGGE tracks more than 3,600 firms, covering approximately $99 \%$ of US equity market. All of the firms in this study were selected randomly without excluding any specific sectors. All selected firms moved up (leaders) or down (laggards) by more than $10 \%$ on the chosen day, and their next-day prices were used for all related analysis in this study. This one-year daily data effectively covers the COVID-19 pandemic period, and all stock prices were above $\$ 5$ per share for more meaningful findings.

Table 1 presents the basic information of U.S. stock market indexes, including AGGE, during the period examined. For better comparisons, the numbers of key market indexes are provided in the table as well. SPX, INDU, and CCMP are the symbols used in the Bloomberg platform for S\&P 500, Dow Jones Industrial Average, and NASDAQ Composite Index, respectively.

Table 1. Market indexes and \% change (Sept. 2, 2019 - Sept. 4, 2020)

\begin{tabular}{ccccc}
\hline & AGGE & SPX & INDU & CCMP \\
\hline September 1, 2019 & $1,040.54$ & $2,926.46$ & $26,403.28$ & $7,962.88$ \\
September 4, 2020 & $1,211.77$ & $3,426.96$ & $28,133.31$ & $11,313.13$ \\
Monthly \% Change & 1.28 & 1.32 & 0.53 & 2.97 \\
\% Change for Entire Period & 16.46 & 17.10 & 6.55 & 42.07 \\
\hline
\end{tabular}

The Bloomberg platform shows daily leaders (whose prices went up) and laggards (whose prices went down) for the major market indexes, including the AGGE. We collected 5 to 10 top leaders and laggards every day during this period, and their price changes were all above 10\%. Table 2 shows the total number of firms for both leaders and laggards used in this research. Furthermore, using S\&P sectoral category, the table shows the total number of firms and percentage out of total firms across 11 sectors.

Table 2. Total number of leaders and laggards at sectoral level

\begin{tabular}{|c|c|c|c|c|}
\hline \multirow[b]{2}{*}{ Sectors by S\&P (11 sectors) } & \multicolumn{2}{|c|}{ Leaders } & \multicolumn{2}{|c|}{ Laggards } \\
\hline & Number of Firms by Sector & $\%$ out of Total Firms & Number of Firms by Sector & $\%$ out of Total Firms \\
\hline Consumer Discretionary (CD) & 254 & $14.37 \%$ & 214 & $14.62 \%$ \\
\hline Consumer Staples (CS) & 69 & 3.90 & 52 & 3.55 \\
\hline Energy $(\mathrm{E})$ & 102 & 5.77 & 96 & 6.56 \\
\hline Financial Services (F) & 140 & 7.92 & 140 & 9.56 \\
\hline Healthcare $(\mathrm{H})$ & 656 & 37.10 & 463 & 31.63 \\
\hline Industrial (I) & 168 & 9.50 & 156 & 10.66 \\
\hline Information Technology (IT) & 206 & 11.65 & 170 & 11.61 \\
\hline Material (M) & 42 & 2.38 & 39 & 2.66 \\
\hline Real Estate (R) & 55 & 3.11 & 69 & 4.71 \\
\hline Transportation $(\mathrm{T})$ & 67 & 3.79 & 54 & 3.69 \\
\hline Utility (U) & 9 & 0.51 & 11 & 0.75 \\
\hline TOTAL & 1768 & $100 \%$ & 1464 & $100 \%$ \\
\hline
\end{tabular}




\section{Discussions}

First, we tried to find the price changes for the next trading day for all leaders and laggards used in this research. Investigation into the next-day price change, reversed or not, can provide a meaningful finding in stock market activities. Table 3 shows a summary of the price movements the next day following the double-digit price changes.

Table 3. Next day price movements following double-digit changes

\begin{tabular}{ccccc}
\hline & $\begin{array}{c}\text { Number of firms whose prices } \\
\text { are reversed the next day }\end{array}$ & $\begin{array}{c}\text { Number of firms whose prices are increased } \\
\text { more or declined more the next day }\end{array}$ & $\begin{array}{c}\text { Number of firms whose } \\
\text { prices are unchanged }\end{array}$ & $\begin{array}{c}\text { Total Number } \\
\text { of Firms }\end{array}$ \\
\hline Leaders & $951(54 \%)$ & $804(45 \%)$ & $13(1 \%)$ & 1768 \\
Laggards & $778(53 \%)$ & $679(46 \%)$ & $7(1 \%)$ & 1464 \\
\hline
\end{tabular}

As Table 3 shows, $54 \%$ of daily leaders had reverse price movements, whereas $45 \%$ of the firms had continuous increase in their prices the next day. The table shows similar responses for the daily lagging firms, $53 \%$ and $46 \%$ each. Even though price reversal is more likely the next day, it does not appear to be substantial and meaningful at this point at an aggregate level.

As a next step, we obtained the average next-day percentage change for both leaders and laggards, and the results are shown in Table 4 . As the table shows, the next day percentage change is $0.0099 \%$ for leaders, which can be converted to $0.1974 \%$ monthly change and $2.3689 \%$ annual change. Comparing to the average annual market returns, the annualized return for leaders is lower than the passive investments (using ETFs), as shown in Table 5. This means that a simple strategy of investing in leaders for one-day holding underperforms the average market.

The next-day percentage change for laggards is $-0.4331 \%$, whose monthly and annual returns are -8.6623 and $-103.95 \%$, respectively. Hence, those losing stocks (laggards) experienced continuous losses, which comprise more than $100 \%$ annual loss if a similar strategy of investing in lagging firms for one-day holding is employed. However, if we bet against the laggards using proper strategies such as short selling the laggards, all of their losses will become profits. The returns from short selling will be much higher than the returns of the average markets shown in Tables 1 and 5.

Table 4. Average stock price and percentage change for daily trading (holding for one day)

\begin{tabular}{cccccc}
\hline & $\begin{array}{c}\text { Average Stock } \\
\text { Price }(\$)\end{array}$ & $\begin{array}{c}\text { Average Daily \% Change } \\
\text { (standard deviation) }(\%)\end{array}$ & $\begin{array}{c}\text { Average Next Day \% Change } \\
\text { (standard deviation) }(\%)\end{array}$ & $\begin{array}{c}\text { Monthly \% } \\
\text { Change }(\%)\end{array}$ & $\begin{array}{c}\text { Annual \% } \\
\text { Change }(\%)\end{array}$ \\
\hline Leaders & 28.26 & $25.45(25.23)$ & $0.0099(12.75)$ & 0.1974 & 2.3689 \\
Laggards & 23.09 & $18.66(8.70)$ & $-0.433(10.32)$ & -8.6623 & -103.95 \\
\hline
\end{tabular}

Note. Monthly and annual returns are obtained from daily $\%$ changes by assuming 20 trading days monthly and 240 days annually.

Table 5. Annual rate of return for S\&P 500, DJIA, and NASDAQ 100 (dividend payments included) (\%)

\begin{tabular}{cccc}
\hline & Sept. 2015 - Sept. 2020 (5 years) & Sept. 2010 - Sept. 2020 (10 years) & Sept. 2000 - Sept. 2020 (20 years) \\
\hline SPY for S\&P 500 & $14.31 \%$ & $15.02 \%$ & $6.24 \%$ \\
DIA for DJIA & 14.01 & 13.60 & 7.15 \\
QQQ for NASDAQ 100 & 24.22 & 22.34 & 6.18 \\
\hline
\end{tabular}

In order to confirm the previous finding, we performed a correlation coefficient test between daily percent change and next day percent change. The results are shown in Table 6.

A value of -0.1272 for leaders indicates that, as daily positive $\%$ change is getting bigger, there is a better chance that the next day's \% change declines, even though it can be mild. This implies that, if one stock is increased too much, there might be a mild reversal the next day. A figure of -0.0687 for laggards indicates that, as daily \% change declines, the next day's \% change is mildly positive. This implies that, if one stock declines too much, there will be a better chance that the stock will mildly rise or recover the next day. However, both numbers are close to zero, and this could mean that, between the two, there is no meaningful positive or negative relationship present. 
The slope of leaders $(-0.1272)$ is greater than that of laggards $(-0.0687)$, so the reversal for the leaders can be greater than the next day recovery for the laggards. The size of reversal of increased stocks can be slightly higher than the recovery of the declined stocks.

Table 6 . Correlation coefficient between daily $\%$ change and next day $\%$ change

\begin{tabular}{cl}
\hline Leaders & -0.1273 \\
Laggards & -0.0687 \\
\hline
\end{tabular}

To improve the robustness of previous findings, we conducted further analyses, as shown in Tables 7 (for leaders) and 8 (for laggards). Even though the results are not strong, Table 7 shows that those that increased more than $30 \%$ showed $-5.38,0.77,-2.58,-0.33 \%$ losses the next day. Leaders can face the mild tendency that the higher the daily percent change, the more likely the next-day losses. In addition, those that have declined more than $30 \%$ have recovered $12.46,4.90$, and $-0.11 \%$ (small loss), respectively, the next day. These findings confirm the correlation coefficient shown above, even though it is not strong.

Table 7 . Average next day $\%$ change by daily $\%$ change (leaders)

\begin{tabular}{ccc}
\hline Daily $\%$ Change & Average Next \% Change & Number of Firms \\
\hline $100 \%$ or Higher Gain & $-5.38 \%$ & 27 \\
$50-99 \%$ & 0.77 & 73 \\
$40-49 \%$ & -2.58 & 65 \\
$35-39 \%$ & -0.33 & 74 \\
$30-34 \%$ & -0.22 & 110 \\
$25-29 \%$ & -0.65 & 172 \\
$20-24 \%$ & 1.25 & 340 \\
$15-19 \%$ & -0.16 & 528 \\
$10-14 \%$ & 0.25 & 379 \\
\hline
\end{tabular}

Table 8 . Average next day $\%$ change by daily $\%$ change (laggards)

\begin{tabular}{ccc}
\hline Daily \% Change & Average Next \% Change & Number of Firms \\
\hline $50 \%$ or Higher Loss & $12.46 \%$ & 15 \\
$40-49 \%$ & 4.90 & 40 \\
$30-39 \%$ & -0.11 & 87 \\
$25-29 \%$ & -2.52 & 98 \\
$20-24 \%$ & -0.93 & 209 \\
$15-19 \%$ & -1.02 & 378 \\
$10-14 \%$ & -0.30 & 637 \\
\hline
\end{tabular}

For the robustness of this research, we decomposed the data into 11 S\&P sectors: consumer discretionary (CD), consumer staples (CS), energy (E), financials (F), health care (H), industrials (I), information technology (IT), materials $(\mathrm{M})$, real estate $(\mathrm{R})$, telecommunications $(\mathrm{T})$, and utilities $(\mathrm{U})$.

Table 9 shows the findings for leaders and Table 10 shows the results for laggards. From previous work, the average next-day change for leaders didn't produce any meaningful returns, with $0.0099 \%$ daily return at an aggregate level. However, if we trade the leaders at the sectoral level every day, the total annual returns for 5 sectors are way higher than those of average markets (Tables 1 and 5). The sectors are utilities (U), real estate (R), consumer discretionary (CD), staples (CS), and information technology (IT), which are shown in Table 9. By contrast, the loss from this type of daily trade produced high losses in 4 sectors: financials (F), materials (M), telecommunications $(\mathrm{T})$, and health care $(\mathrm{H})$. Hence, we need to avoid these 4 sectors, whereas $\mathrm{U}, \mathrm{R}, \mathrm{CD}, \mathrm{CS}$, and IT sectors can produce outperforming returns by simply utilizing daily trading strategy. 
Table 9. Percentage change for leaders at sectoral level

\begin{tabular}{ccccccc}
\hline \multirow{2}{*}{ Sectors } & $\begin{array}{c}\text { Average Closing } \\
\text { Price }\end{array}$ & $\begin{array}{c}\text { Average } \% \\
\text { Increase }\end{array}$ & $\begin{array}{c}\text { Average Next } \\
\text { Day Change }\end{array}$ & $\begin{array}{c}\text { Rank in Next } \\
\text { Day Change }\end{array}$ & $\begin{array}{c}\text { Average } \\
\text { Monthly Change }\end{array}$ & $\begin{array}{c}\text { Average Annual } \\
\text { Change }\end{array}$ \\
\hline CD & $\$ 37.48$ & $25.72 \%$ & $1.15 \%$ & 3 & $23.01 \%$ & $276.18 \%$ \\
CS & 35.39 & 23.47 & 0.81 & 4 & 16.13 & 193.60 \\
E & 19.74 & 27.39 & 0.06 & 6 & 1.23 & 14.80 \\
F & 31.47 & 25.67 & -3.35 & 11 & -66.96 & -803.47 \\
H & 25.41 & 26.53 & -0.20 & 8 & -3.95 & -47.38 \\
I & 26.57 & 26.11 & -0.04 & 7 & -0.77 & -9.19 \\
IT & 35.12 & 22.67 & 0.21 & 5 & 4.19 & 50.26 \\
M & 17.41 & 21.09 & -1.38 & 10 & -27.55 & -330.63 \\
R & 17.64 & 27.47 & 1.71 & 2 & 34.16 & 409.88 \\
T & 39.65 & 28.23 & -1.38 & 9 & -27.53 & -330.38 \\
U & 20.69 & 21.78 & 6.90 & 1 & 127.98 & $1,655.73$ \\
\hline
\end{tabular}

Table 10 shows daily percentage returns for laggards. In previous work, we showed that daily trading strategy didn't work for laggards at an aggregate level. However, we find three positive outperforming sectors: financials $(\mathrm{F})$, telecommunications $(\mathrm{T})$, and real estate $(\mathrm{R})$. These three sectors show substantial reversals the next day, as presented in Table 10. The monthly converted returns are $41.11(\mathrm{~F}), 35.30(\mathrm{~T})$, and $25.53 \%(\mathrm{R})$, respectively. The annualized returns are $493.29,423.56$, and $306.40 \%$, respectively. The other 8 sectors of laggards showed substantial losses from daily trading strategy. Once again, short selling can work for those 8 sectors.

Table 10. Percentage change for laggards at sectoral level

\begin{tabular}{ccccccc}
\hline \multirow{2}{*}{ Sectors } & $\begin{array}{c}\text { Average Closing } \\
\text { Price }\end{array}$ & $\begin{array}{c}\text { Average } \% \\
\text { Decrease }\end{array}$ & $\begin{array}{c}\text { Average Next } \\
\text { Day Change }\end{array}$ & $\begin{array}{c}\text { Rank in Next } \\
\text { Day Change }\end{array}$ & $\begin{array}{c}\text { Average } \\
\text { Monthly Change }\end{array}$ & $\begin{array}{c}\text { Average Annual } \\
\text { Change }\end{array}$ \\
\hline CD & $\$ 24.13$ & $19.05 \%$ & $-1.78 \%$ & 9 & $-35.66 \%$ & $-427.91 \%$ \\
CS & 29.60 & 18.29 & -3.36 & 10 & -67.17 & -806.08 \\
E & 18.88 & 22.61 & -0.71 & 8 & -14.13 & -169.55 \\
F & 24.46 & 17.15 & 2.06 & 1 & 41.11 & 493.29 \\
H & 20.82 & 18.04 & -0.59 & 6 & -11.87 & -142.45 \\
I & 24.17 & 18.75 & -0.66 & 7 & -13.11 & -157.35 \\
IT & 35.02 & 17.53 & -0.52 & 5 & -10.34 & -124.04 \\
M & 18.53 & 16.95 & -0.08 & 4 & -1.65 & -19.75 \\
R & 16.03 & 22.89 & 1.28 & 3 & 25.53 & 306.40 \\
T & 27.23 & 18.42 & 1.76 & 2 & 35.30 & 423.56 \\
U & 33.58 & 17.45 & -5.38 & 11 & -107.65 & $-1,291.85$ \\
\hline
\end{tabular}

Table 11 shows the returns for each sector using the representative ETFs for the same period. By comparing the returns of the 5 sectors $(\mathrm{U}, \mathrm{R}, \mathrm{CD}, \mathrm{CS}$, and IT) from leaders and 3 sectors $(\mathrm{F}, \mathrm{T}$, and $\mathrm{R}$ ) from laggards to the corresponding ETFs, more meaningful findings can be obtained. First, the annual returns from simple daily trading for 4 sectors $(\mathrm{U}, \mathrm{R}, \mathrm{CD}$, and $\mathrm{CS})$ are much higher than those of corresponding sectoral ETFs: 1,655.73\% vs. $-1.84 \%$ for U; $409.88 \%$ vs. $-7.91 \%$ for R; $276.18 \%$ vs. $24.77 \%$ for CD; and $193.60 \%$ vs. $10.97 \%$ for CS.

The annual returns of the simple trading for the IT sector are similar to those of the corresponding ETF, 50.26\% vs. $50.67 \%$. Hence, the findings at the sectoral level are more meaningful and robust by showing that the simple strategy outperforms both the market average and corresponding sectoral ETFs for leaders.

Similar findings are obtained for laggards as well. The annual returns of the simple trading strategy for 3 sectors (F, $\mathrm{T}$, and $\mathrm{R}$ ) were $493.29,423.56$, and $306.40 \%$, respectively, whereas they were $-3.63,2.79$, and $-7.91 \%$, respectively. Thus, the daily trading strategy outperformed the returns of average total market and corresponding sectors. 
Table 11. Annual returns for sectoral ETF (Sept. 1, 2019 - Sept. 4, 2020)

\begin{tabular}{ccc}
\hline Sectors & ETF & Rate of Return $(\%)$ \\
\hline Consumer Discretionary & XLY & 24.77 \\
Consumer Staples & XLP & 10.97 \\
Energy & XLE & -33.97 \\
Financials & XLF & -3.62 \\
Health Care & XLV & 19.51 \\
Industrials & XLI & 5.11 \\
Information Technology & XLK & 50.67 \\
Materials & XLB & 16.31 \\
Real Estate & IYR & -7.91 \\
Telecommunications & IYZ & 2.79 \\
Utilities & XLU & -1.84 \\
\hline Market Index & SPY & 17.10
\end{tabular}

Note. All the dividend payments are included. Each ETF in this paper is the most liquid and biggest in terms of net asset value among each sectoral ETFs. They are issued by iShares (IYR and IYZ) and State Street SPDR (remaining 9 ETFs). The expense ratio for 9 ETFs of SPDR is $0.13 \%$, whereas it is $0.42 \%$ for both IYR and IYZ. The data source is www.etfdb.com

\section{Conclusions}

A simple strategy of investing in randomly selected leaders for one-day holding is ineffective, which suggests that the simple price surge or crash by itself does not provide any meaningful predicting power and strategy in investment. The results confirm a lack of over-reaction, which puts them at odds with the findings by Kudryavtsev (2019) However, similar strategy for short-selling randomly selected laggards produces huge annual return outperforming the average market.

In general, investors tend to believe that rising stocks can maintain their momentum going forward, whereas the losing stocks look cheaper. Hence, investors believe that, when they randomly select firms (from leaders and laggards) for short-term trading due to momentum expectations and cheaper stock prices, they can outperform the market. However, we find that this simple trading strategy does not work, and it can underperform the average market.

Even though the simple daily trading strategy for randomly selected leaders and laggards does not work at an aggregate level, this paper shows that the trading strategy works well if we narrow down our selections into sectors. From the leaders, there are 5 sectors (utilities, real estate, consumer discretionary, consumer staples, and information technology) that outperform the average market. Among the laggards, there are 3 sectors (financials, telecommunications, and real estate) whose returns outperformed the average markets. In addition, short selling can work well in the remaining 8 sectors for laggards.

This paper uses one-year daily data, including within the COVID-19 pandemic period, and future research is possible by employing data from longer periods whose findings are more robust. In addition, future research can be extended into the firm level, from which more common fundamental factors can be found. Furthermore, we performed this research by employing simple data analyzing tools, whereas future research can employ more advanced statistical models such as time-series tools.

\section{References}

Bratian, V., Opreana, C., \& Bucur, A. (2017). Evaluation of the Stock Quote - Stochastic Approach, Market Efficiency and Technical Analysis. International Journal of Economics and Financial Issues, 7(5), 307-316. http://www.econjournals.com/index.php/ijefi/article/view/5254/pdf

De Souza, M. J. S., Ramos, D. G. F., Pena, M. G., Sobreiro, V. A., \& Kimura, H. (2018). Examination of the Profitability of Technical Analysis Based on Moving Average Strategies in BRICS. Financial Innovation, 4(3), 1-18. https://doi.org/10.1186/s40854-018-0087-z

Dev Shah, H. I., \& Zulkernine, F. (2019). Stock Market Analysis: A Review and Taxonomy of Prediction Techniques, International Journal of Financial Studies, 7(2), 1-22. https://doi.org/10.3390/ijfs7020026

Kudryavtsev, A. (2017). "I'll Think about It Tomorrow": Price Drifts Following Large Pre-Holiday Stock Price Moves. The Review of Finance and Banking, 9(2), 43-62. https://econpapers.repec.org/RePEc:rfb:journl:v:09:y:2017:i:2:p:043-062 
Kudryavtsev, A. (2017). The Effect of Preceding Sequences on Stock Returns. European Financial and Accounting Journal, (4), 83-96. https://doi.org/10.18267/j.efaj.202

Kudryavtsev, A. (2018). The Availability Heuristic and Reversals Following Large Stock Price Changes. Journal of Behavioral Finance, 19(2), 159-176. https://doi.org/10.1080/15427560.2017.1374276

Kudryavtsev, A. (2019). The Effect of Trading Volumes on Stock Returns Following Large Price Moves. Economic Annals, 64(220), 85-116. https://doi.org/10.2298/EKA1920085K

Kung, J. J., \& Wong, W. K. (2009). Profitability of Technical Analysis in the Singapore Stock Market: before and after the Asian Financial Crisis. Journal of Economic Integration, 24(1), 135-150. https://doi.org/10.11130/jei.2009.24.1.135

Lai, H. W., Chen, C. W., \& Huang, C. S. (2010). Technical Analysis, Investment Psychology, and Liquidity Provision: Evidence from the Taiwan Stock Market. Emerging Markets Finance \& Trade, 46(5), 18-38. https://doi.org/10.2753/REE1540-496X460502

Lo, A. W., Mamaysky, H., \& Wang, J. (2000). Foundations of Technical Analysis: Computational Algorithms, Statistical Inference, and Empirical Implementation. The Journal of Finance, 55(4), 1705-1765. https://doi.org/10.1111/0022-1082.00265

Moosa, I., \& Li, L. (2014). Technical and Fundamental Trading in the Chinese Stock Market: Evidence Based on Time-Series and Panel Data. Emerging Markets Finance and Trade, 47(1), 23-31. https://doi.org/10.2753/REE1540-496X4701S103

Rosillo, R., de la F., D., \& Brugos, J. A. L. (2013). Technical Analysis and the Spanish Stock Exchange: Testing the RSI, MACD, Momentum and Stochastic Rules using Spanish Market Companies. Applied Economics, 45(12), 1541-1550. https://doi.org/10.1080/00036846.2011.631894

Wong, W. K., Manzur, M., \& Chew, B. K. (2003). How Rewarding Is Technical Analysis? Evidence from Singapore Stock Market. Applied Financial Economics, 13(7), 543-551. https://doi.org/10.1080/0960310022000020906

\section{Copyrights}

Copyright for this article is retained by the author(s), with first publication rights granted to the journal.

This is an open-access article distributed under the terms and conditions of the Creative Commons Attribution license (http://creativecommons.org/licenses/by/4.0/). 